\title{
The Prevalence of Extreme Middle-Eastern Ideologies among Some Nigerians
}

\author{
AG Ahmed ${ }^{1,2}$, Moses David Audu ${ }^{3}$, Wagdy Loza ${ }^{4,5}, \&$ Artur Maximenco ${ }^{6}$ \\ ${ }^{1}$ Royal Ottawa Mental Health Centre, Ottawa, Canada \\ ${ }^{2}$ School of Criminology, University of Ottawa, Ottawa, Canada \\ ${ }^{3}$ University of Jos, Jos, Nigeria \\ ${ }^{4}$ Queen's University, Kingston, Canada \\ ${ }^{5}$ Correctional Service of Canada, Ret. \\ ${ }^{6}$ University of Toronto, Toronto, Canada \\ Correspondence: AG Ahmed, Integrated Forensic Program, Brockville Mental Health Centre, Brockville, \\ Ontario, K6V 5W7, Canada. Tel: 1-613-722-6521 ext. 2604. E-mail: ag.ahmed@theroyal.ca
}

Received: May 16, 2013 Accepted: June 13, 2013 Available online: June 29, 2013

doi:10.11114/ijsss.v1i2.167 URL: http://dx.doi.org/10.11114/ijsss.v1i2.167

\begin{abstract}
Over the past decade, a small extremist Islamic sect agitating against Western civilization has grown to become the biggest challenge to Nigerian internal security, a serious threat to international security and peace, and has earned the country the unenviable international reputation of a terrorist state. The radicalization of members of the group is driven majorly by extreme Middle-Eastern Islamic religious ideologies. In this study, 99 Nigerian participants (51 Christians and 48 Muslims) completed the Assessment and Treatment of Radicalization Scale (ATRS; Loza, 2007; formally the Belief Diversity Scale, BDS; Loza, 2007). The ATRS is a 33-item, six subscale instrument that is designed to quantitatively measure Middle-Eastern extremist ideologies in areas of risk reported in the literature. Results demonstrated reliability and validity of the ATRS as well as indicated the prevalence of Middle-Eastern extremists' ideologies among Nigerian Muslims. Current findings are consistent with those obtained from previous studies. These findings suggest that the ATRS could be used as an objective tool to measure Middle-Eastern religious extremism.
\end{abstract}

Keywords: Middle-Eastern ideologies, radicalization/extremism/terrorism, assessment tool, Nigeria

\section{Introduction}

Since the 9/11 attack in New York City, the world has become more familiar with extreme religious beliefs, attitudes, underlying ideologies, and their potential consequences. Unmentioned in the West, these potentially volatile sentiments have been escalating in the Middle-East over the past three decades. These ideologies have been blamed for the recent extremism and violent actions that are committed around the world. To explain this religious extremism, some have cited Huntington's (1993) warning about the inevitable "clash of civilizations" because of the competing religious ideologies of Western, traditionally Christian countries, and Islamic countries. Others, however, have provided explanations or normalizations based on religious, sociological, economical, psychological, and political factors rather than solely religious explanations (see review by Loza, 2007). It has been reported that extreme or radical Islamic beliefs are both associated with and reliably precede violent acts perpetrated by Middle-Eastern terrorists (Pipes, 2008).

Until recently, Nigeria has always been known to its citizens and foreigners as a country where a variety of religions coexist in harmony and healthy tolerance; however, about a decade ago, the birth of an extremist Islamic sect, Boko Haram (also known as Ahlulsunna wal'jama'ah hira) on the campus of the University of Maiduguri, Borno State in Northern Nigeria eroded this peaceful image. The philosophy of this sect is rooted in the observance and practice of Islamic orthodoxy, which holds Islamic culture supreme and execrates Western civilization, including formal Western education (Isa, 2010). This sect, whose ideological goal of overthrowing the Nigerian secular government and imposing the Islamic Sharia government, has remained unchanged, considering non-members disbelievers and wrong doers. The sect has claimed responsibility for targeted bombing of military barracks, police stations, the United Nations (UN) House, and churches in the name of religion (Onuoha, 2012). 
Several studies involving field research on aspects of terrorism have been conducted. For example, Post, Sprinzak, and Denny (2003) conducted semi-structured interviews with 35 incarcerated terrorists who were involved in the Israeli-Palestinian conflict. Berko and Erez (2007) also interviewed Palestinians incarcerated for terrorist acts, although they focused on female interviewees and examined the role of gender in the decision to engage in such acts. Sageman (2004) also conducted research on terrorists; following the 9/11 attacks, he began to collect biographical material on approximately 400 al Qaeda terrorists to test the validity of the conventional wisdom on terrorism. Ansari, Cinnirella, Rogers, Loewenthal, and Lewis (2006) examined attitudes (potentially extreme) among British Muslims. Ibrahim (1980) conducted interviews with two groups of the terrorists who were involved in bloody confrontations with the regime in Egypt resulting in casualties. Other studies involved interviews with individuals who committed terrorist acts (Bakker, 2006; Post, Merari, \& Ganor, 2008; Stern, 1999, 2003).

However, it is important to note that these studies examined individuals who have already been identified as terrorists; our research sought to prospectively identify those individuals who had extreme beliefs that may be associated with the willingness to participate in terrorist acts. In spite of the above-noted research, there are few studies involving field research relevant to this type of extreme, and most of those studies were based on archival information, involved secondary analysis of data (Silke, 2008), or did not use psychometrics or questionnaires. One reason for the latter drawback is that there were no validated instruments to assess the characteristic beliefs of terrorists. Indeed, the interview data gathered in the above-mentioned studies provided some original knowledge about the characteristics of terrorists, from which such instruments could be developed.

A great deal of the accumulated knowledge about the aforementioned extremism has been gained from media reports, but reporters often reflect the individual or organizational views of the agencies with whom they are affiliated. These views are often biased towards or against particular political and religious perspectives. However, extremism is an important topic that must be objectively and empirically investigated. Unfortunately, such investigations have been rare and sporadic. There is a need for further research in this area.

The paucity of research that includes the use of psychometrics or questionnaires can be attributed to a number of problems: a) there are very few researchers who have an in-depth understanding of the religious, cultural, psychological, historical, political, linguistic, and social backgrounds of the populations from which much of the extremist ideologies originate; $b$ ) there is no advanced training available in educational institutions for dealing with the issues involved with the ideologies of extremists; c) there is a particular need for sensitivity in dealing with these ideologies, as they are framed in terms of religious beliefs; d) there is the possibility of being accused of racism or prejudice towards a particular religion or ideology, along with the consequences that such accusations might entail (e.g., possible violent reprisals against the researchers); and most relevantly from a psychological perspective, e) there were no adequate objective scales to measure extreme beliefs for research purposes.

This latter lacuna was addressed in the development of the Assessment and Treatment of Radicalization Scale (ATRS; Loza, 2007; formally known as the Beliefs Diversity Scale, BDS; Loza, 2007). The ATRS is a theoretically driven, empirically validated, self-report instrument, constructed to cover the areas in the literature that are commonly reported to be indicative of and related to religious extreme beliefs (Loza, 2007). We are not aware of the existence of any other scale that has been specifically designed to measure these extreme ideologies. Additionally, there are practical reasons for the development of such a scale. For example, the ATRS could be used by agencies that rely on risk assessments to identify individuals with extreme Middle-Eastern ideologies or individuals who have beliefs supporting violence. The scale could be used to guide and inform policies related to prevention of these violent acts or responses to terrorist threats and violence. It could also be used therapeutically in interventions to assess changes. Finally, the ATRS could be used for research purposes in this under-explored area.

Our goal in conducting this research was to assess the prevalence of Middle-Eastern extreme ideologies among some Nigerians. To do this, we compared the responses on the ATRS of Christian and Muslim participants. We hypothesized that participants of Christian and Muslim faiths would differ in their responses to the ATRS, with participants of the Muslim faith scoring significantly higher on the ATRS than their Christian counterparts. This hypothesis is based on the reported prevalence of Middle-Eastern extreme religious views around the world (Littman, 2005; Loza, 2010a; Loza, 2010b; Loza, El-Fatah, Prinsloo, Hesslink, \& Seidler, 2011; Manji, 2003; Sayyed, 2005).

\section{Methods}

\subsection{Participants}

Involved in this study were 99 adults participants, selected through convenience sampling (see Table 1 for a summary of demographic characteristics of participants.) 
Table 1. Demographic Characteristics of participants ( $\mathrm{n}=99)$

\begin{tabular}{|c|c|c|c|c|}
\hline \multirow[t]{2}{*}{ Demographics } & \multicolumn{2}{|c|}{$\begin{array}{c}\text { Christians } \\
(\mathrm{n}=51)\end{array}$} & \multicolumn{2}{|c|}{$\begin{array}{c}\text { Muslims } \\
(\mathrm{n}=48)\end{array}$} \\
\hline & $\mathrm{M}$ & SD & $\mathrm{M}$ & SD \\
\hline \multirow[t]{2}{*}{ Age } & 29.96 & 10.52 & 24.00 & 8.13 \\
\hline & \multicolumn{2}{|c|}{ Freq $(\%)$} & \multicolumn{2}{|c|}{ Freq $(\%)$} \\
\hline \multicolumn{5}{|l|}{$\underline{\operatorname{Sex}}$} \\
\hline$\overline{\mathrm{M}}$ & 58.82 & & 33.33 & \\
\hline $\mathrm{F}$ & 41.18 & & 66.67 & \\
\hline \multicolumn{5}{|l|}{ Race } \\
\hline African & 100.00 & & 100.00 & \\
\hline \multicolumn{5}{|l|}{ Education } \\
\hline$\overline{\text { Secondary }}$ & 7.84 & & 2.08 & \\
\hline College & 11.76 & & 25.00 & \\
\hline Higher education & 80.40 & & 72.92 & \\
\hline \multicolumn{5}{|l|}{ Marital Status } \\
\hline Single & 58.82 & & 72.92 & \\
\hline Married & 41.18 & & 27.08 & \\
\hline \multicolumn{5}{|l|}{ Occupation } \\
\hline Students & 39.22 & & 72.92 & \\
\hline Employees \& professionals & 60.78 & & 27.08 & \\
\hline
\end{tabular}

\subsection{Measures}

The ATRS consists of six subscales, with each subscale designed to tap into a prominent ideological theme. The first subscale reflects negative Attitudes towards Israel. The Israeli-Palestinian conflict is considered to be one of the central sources of grievance promoted by many extremists (Ameen, 1993; Mockaitis, 2007). The second subscale measures predominant Political Views that are advocated by Middle-Eastern extremists (e.g., opposing secular laws and governments, advocating for the implementation of the Sharia [Islamic] law; Ibrahim, 1988; Mockaitis, 2007). The third subscale assesses participants' Attitudes towards Women. These current, extreme, and mainly repressive attitudes were generally foreign to most Middle-Eastern countries and were not promoted prior to the 1970s (Kanany-Minesot, 1995). The fourth subscale measures negative Attitudes towards Western Culture. Middle-Eastern extremists have been vocal in their rejection of Western culture (Mazarr, 2007; Mockaitis, 2007; Tanveer, 2005), claiming that Western civilization is corrupt (McCauley, 2002) and that the West is trying to undermine their religion (Orbach, 2001). Extremists in the Muslim countries generally maintain prevalent negative attitudes towards non-Muslim cultures (Littman, 2005; Manji, 2003; Mockaitis, 2007; Sayyed, 2005). The fifth subscale, Religiosity, assesses the respondents' commitment to their religion. Extremists use religion to advocate for their cause and to recruit new pools of extremists (Hafez, 2003; Ibrahim, 1988; Isam, 2006; Lotfi, Ali, \& Kamel, 1993; Mockaitis, 2007; Sageman, 2004; Schwind, 2005). Some questions in this subscale tap into extreme religious views that are common in the Middle-East. The sixth subscale, Condoning Fighting, measures views that condone fighting and promote acts of violence as a means for the revival of religion with the goal of destroying infidels (e.g., atheists and nonbelievers in Islam) and achieving one world under the Islamic religion (Sageman, 2004; Schwind, 2005). The final subscale is a validity scale that indicates whether participants misunderstood the items, answered carelessly, or deliberately attempted to conceal their true answers. Items included in this subscale are additional to the 33 items of the ATRS. The total score consists of the answers to the items included in the first six subscales (i.e., items included in the validity subscale are not included in the total scale score.) Three previous studies have demonstrated the reliability and validity of the ATRS (Loza, 2010a; Loza, 2010b; Loza et al., 2011).

\subsection{Procedure}

The current study focused on Nigeria because it is known for its religious and cultural diversity, is not a Middle-Eastern country, and because of Boko Haram's recent attacks are believed to be religiously motivated. The sect, Boko Haram, has been advocating and claimed responsibility for violence as a means of establishing Sharia law in the country. It is similar to the Muslim Brotherhood which is currently strong in Egypt and other 
Arab countries. The study was conducted over a 12 week period in the city of Jos, Northern Nigeria. Jos is a cosmopolitan university city and is inhabited by a nearly equal number of Christians and Muslims, although not all are necessarily strict adherents of the faiths. Participants were recruited by volunteer research assistants who delivered the ATRS to participants in their offices and classrooms. The vast majority (90\%) of the people who were approached agreed to participate in the study. The research assistants explained the purpose of the study and provided clarification upon request. Participants were advised that the purpose of the study was to validate a scale about diversity of religious beliefs among individuals of differing religious affiliations. They were assured anonymity and were advised to not identify themselves in any form. Participants were free to decline participation and did not receive monetary compensation. All participants read and spoke English fairly well and indicated that they fully comprehended the purpose of the study. There was no difference between the demographic characteristics of individuals who refused participation and those of participants of the study. All responses were anonymous and contained personal information that could lead to identification of participants. Data were entered into a database by the research assistants. The city of Jos witnessed the last major attack by Boko Haram a year prior to the start of data collection, as well as numerous and regular "minor attacks" over the past year, at which time the study was being conducted.

\section{Results}

The main findings of this study are summarized in Tables 2 to 4 . All items correlated significantly with their respective subscales. The correlations between ATRS subscale scores and the total score ranged from .70 to .86 . The correlations between subscales ranged from .31 to .88 (see Table 2.)

Table 2. Coefficient Alphas for the ATRS subscales, Range of Item to Subscale, and Subscales to Total scale Correlations ( $\mathrm{n}=99)$

\begin{tabular}{|c|c|c|c|c|c|}
\hline \multirow[t]{3}{*}{ ARTS Subscales } & \multirow{3}{*}{$\begin{array}{l}\text { Range of item / } \\
\text { subscale } \\
\text { correlations }\end{array}$} & \multirow[t]{3}{*}{ Mean } & \multirow[t]{3}{*}{ SD } & \multicolumn{2}{|c|}{$\begin{array}{l}\text { Total scale / subscale correlations } \\
\text { and Confidence Intervals }\end{array}$} \\
\hline & & & & $\mathrm{r}$ & $(95 \% \mathrm{CI})$ \\
\hline & & & & $\mathrm{r}$ & $(95 \% \mathrm{CI})$ \\
\hline Attitude towards Israel & $(.63-76)^{*}$ & 9.03 & 3.11 & 0.73 & $(.91-.95)$ \\
\hline Political Views & $(.34-68)^{*}$ & 12.94 & 3.01 & 0.76 & $(.99-1.03)$ \\
\hline Attitudes toward women & $(.40-.77)^{*}$ & 9.01 & 2.61 & 0.76 & $(.99-1.03)$ \\
\hline Attitude toward Western culture & $(.69-.74)^{*}$ & 12.4 & 3.69 & 0.77 & $(.99-.1 .04)$ \\
\hline Religiosity & $(.46-.70)^{*}$ & 18.05 & 3.5 & 0.70 & $(.84-.89)$ \\
\hline Fighting & $(.44-.80)^{*}$ & 18.76 & 6.05 & 0.86 & $(.1 .21-1.25)$ \\
\hline Total ARTS & & 89.67 & 18.53 & & \\
\hline
\end{tabular}

Note: $* \mathrm{p}<.0001$.

The comparisons of mean ATRS scores of Christian and Muslim participants are shown in Table 3. Muslim participants scored significantly higher than the Christians on all the ATRS scales.

Table 3. Comparisons between the scores of Christians and Muslims on the ATRS scales ( $n=99)$

\begin{tabular}{lccccc}
\hline \multicolumn{1}{c}{ Subscale } & \multicolumn{2}{c}{$\begin{array}{c}\text { Christians } \\
(\mathrm{n}=51)\end{array}$} & \multicolumn{2}{c}{$\begin{array}{c}\text { Muslim } \\
(\mathrm{n}=48)\end{array}$} & $\begin{array}{c}\text { F } \\
\text { F value } \\
\end{array}$ \\
& $\mathrm{M}$ & $\mathrm{SD}$ & $\mathrm{M}$ & $\mathrm{SD}$ & $(1,79)$ \\
\hline Attitude toward Israel & 7.60 & $(2.90)$ & 10.54 & $(2.58)$ & $28.12^{*}$ \\
& 11.57 & $(2.83)$ & 14.39 & $(2.62)$ & $26.48^{*}$ \\
$\begin{array}{l}\text { Political Violence } \\
\text { Attitudes towards women }\end{array}$ & 7.35 & $(1.99)$ & 10.77 & $(1.97)$ & $73.71^{*}$ \\
& & & & & \\
Attitudes towards Western Culture & 10.35 & $(2.89)$ & 14.58 & $(3.17)$ & $48.16^{*}$ \\
Religiosity & & & & & \\
$\begin{array}{l}\text { Fighting } \\
\text { TOTAL ATRS }\end{array}$ & 16.17 & $(3.43)$ & 20.04 & $(2.41)$ & $41.60^{*}$ \\
\hline & 15.72 & $(6.14)$ & 21.80 & $(3.96)$ & $35.79^{*}$ \\
\hline & 77.14 & $(14.63)$ & 102.80 & $(11.70)$ & $93.48^{*}$ \\
\hline
\end{tabular}

Note: $* \mathrm{p}<.0001$. 
To investigate the trend of participant responses on the ATRS, participants were grouped into Low (Total scores $\leq 77$ ), Medium ( $>77-\leq 98)$, and High (>98) scoring groups, with approximately $33 \%$ of participants falling in each group. Table 4 shows that $60.42 \%$ and $5.88 \%$ of scores obtained by Muslim and Christian participants respectively fell in the High group, while $4.17 \%$ and $56.86 \%$ of scores obtained by Muslim and Christian participants respectively fell in the Low group.

Table 4. Percentage of religion groups on the low, medium and high scores of the ATRS Scale ( $n=99$ )

\begin{tabular}{lcc}
\hline ARTS GROUP & $\begin{array}{c}\text { Christians } \\
(\mathrm{n}=51) \\
\%\end{array}$ & $\begin{array}{c}\text { Muslim } \\
(\mathrm{n}=48) \\
\%\end{array}$ \\
\hline Low $(<=77)$ & 56.86 & 4.17 \\
Medium $(>77-<=98)$ & $37.26 \%$ & 35.41 \\
High $=(>98)$ & $5.88 \%$ & 60.42 \\
\hline
\end{tabular}

\section{Discussion}

The prevalence of extreme Middle-Eastern ideologies among some Nigerians was demonstrated. The reliability of the ATRS was also evidenced by the strong correlations between the items and their respective subscales, as well as the strong correlations between the total ATRS score and the ATRS subscale scores.

The discriminant validity of the ATRS was demonstrated by the predicted differences among the scores of participants of Christian and Muslim religious affiliations. The prevalence of the extreme Middle-Eastern ideologies was demonstrated by the fact that participants of the Muslim faith scored significantly higher on the ATRS than their Christian counterparts.

The fact that $60.42 \%$ of the scores of Muslim participants fell into the group designated as "High" on the ATRS, whereas the bulk of the scores of Christian participants fell into the "Medium" and "Low" scoring groups demonstrates significant external validity of the ATRS as an instrument specifically designed to measure extreme beliefs increasingly seen in Middle-Eastern ideologies.

The results of this study support the hypothesis about the prevalence of Middle-Eastern extremist ideologies as well as the concerns expressed by several Arab and Western writers regarding the prevalence of extreme Middle-Eastern ideologies originating in the Arab world.

This study is important for several reasons. First, the results support the prevalence of extreme ideologies among the Muslim population around the world. Second, the findings support the effectiveness of the ATRS as a reliable and valid scale for measuring extreme Middle-Eastern ideology. To our knowledge there is no other known objective scale that is specifically designed to measure the extreme religious ideologies that originate from the Middle-East. Third, the generalizability of the ATRS as an instrument for assessing Middle-Eastern extremism is increased.

It is important for social scientists to find ways to defuse the current polarization of the world into ideological rivals based on religious beliefs. We suggest that grievances that gave rise to such extremism could be addressed through the abolishment of politicalization of religion and the availability of educational information advocating acceptance and mutual respect of others' religious beliefs and cultures.

The ATRS has several advantages. First, because the ATRS is a self-report scale, it ensures maximal objectivity by avoiding possible misinterpretation of participants' responses and minimizes assessor biases, which is important given the sensitive nature of the area of assessment. Second, the ATRS is more convenient and economical to use than lengthy interviews. Participants simply provide numeric responses indicating the degree of agreement with the items, and the scale usually takes only a few minutes to complete. Scoring the test is straightforward, as basic interpretation requires minimal professional involvement. A third advantage of the ATRS is the large proportion of dynamic statements which could be used to measure the extent to which changes in beliefs and ideologies occur over time, following exposure to contrary information, or intervention. Should subsequent research confirm the validity of the scale, the ATRS could be used to identify those at risk of escalation to terrorism and could potentially be used as part of individualized intervention programs. For example, extreme erroneous thoughts indicated by the endorsement of particular statements could be challenged during treatment. 
Similar to the previous studies conducted by one of the authors, the current study has the following limitations: a) participants were selected using convenience rather than randomized sampling and collateral important data about the participants (e.g., background- and personality-related information) was not collected; b) concurrent validity of the ATRS could not be further assessed due to the lack of other available assessment measures; and c) the use of the current data for future predictive studies (e.g., to test whether highly extremist responses will predict terrorist acts) is not possible.

Future studies involving participants from other regions of the country, participants of other religious ideations (i.e., non-Muslims and non-Christians), and larger samples will provide a better understanding of this serious phenomenon and insight into targeted intervention in order minimize the human and economic burden of Middle-Eastern extremism. As previously suggested by Loza et al. (2011), establishing norms and cut-off scores through the use of large and diverse samples will aid in the classification of individuals based on their risk of escalation to terrorism and need for intervention. This approach advocates an intervention that is more responsive to the individual and could potentially minimize the theoretical detrimental effect of treating high and low scorers alike.

Finally, due to the sensitive nature of the ATRS and the topics it assesses, it is imperative that caution be exercised in order to guard against any possible abuse of the scale. Therefore, we recommend that mental health professionals involved in the use of the ATRS undergo comprehensive training on the administration of the scale and interpretation of results prior to using it.

\section{Acknowledgments}

We wish to express our appreciation to participants involved in this study. We also wish to express our gratitude to Dr. Aishatu, Dr. Armiya'u, Dr. Oloche, and Dr. Adole for involvement in the data collection procedures, as well as to Erika Jansman-Hart for her assistance with the preparation of the manuscript. The opinions expressed are those of the authors and do not represent the views of any institution.

\section{References}

Ameen, H. A. (1993). El-Mowagha: Gzoor El-Erhab [The Confrontation: Roots of Terrorism; pp. 10-18]. Cairo, Egypt: Egyptian Organization for Publishing Books.

Ansari, H., Cinnirella, M., Rogers, M. B., Loewenthal, K. M., \& Lewis, C. A. (2006). Perceptions of martyrdom and terrorism amongst British Muslims. In Rogers, M., Lewis, C. A., Loewenthal, K. M., Cinnirella, M., Amlot, R., \& Ansari, H. (Eds.), Proceedings of the British Psychological Society Seminar Series Aspects of Terrorism and Martyrdom, eCOMMUNITY: International Journal of Mental Health \& Addiction.

Bakker, E. (2006). Jihadi terrorists in Europe their characteristics and the circumstances in which they joined the jihad: An exploratory study. The Hague, Netherlands: Netherlands Institute of International Relations Clingendael.

Berko, A., \& Erez, E. (2007). Gender, Palestinian women, and terrorism: Women's liberation or oppression. Studies in Conflict \& Terrorism, 30(6), 493-519. http://dx.doi.org/10.1080/10576100701329550

Hafez, M. M. (2003). Why Muslims rebel: Repression and resistance in the Islamic world. Boulder, CO: Lynne Rienner Pub.

Huntington, S. P. (1993). The clash of civilizations and the remaking of world order. New York, NY: Touchstone.

Ibrahim, S. E. (1980). Anatomy of Egypt's militant Islamic groups: Methodological note and preliminary findings. International Journal of Middle East studies, 12(4), 423-453. http://dx.doi.org/10.1017/S0020743800031238

Ibrahim, S. E. (1988). Egypt's Islamic activism in the 1980s. Third World Quarterly, 10(2), 632-657.

Isa, M. K. (2010). Militant Islamist groups in Northern Nigeria. In W. Okumu, \& A. Ikelegbe (Eds.), Militias, rebels and Islamist militants: Human insecurity and state crises in Africa (pp. 313-340). Tshwane (Pretoria), South Africa: Institute of Security Studies.

Isam, S. E. (2006, April 24). Karitat Iktrak El-Ikwan Wa-El-Irhabieen Lil El-Taleem El-Masry [How the terrorist's brothers invaded the Egyptian educational system]. Cairo, Egypt: Rose-El-Yossef.

Kanany-Minesot, G. H. (1995). The Saudi-Islamic invasion to Egypt: A blind apostasy from civilization and a multi-violation of human rights. The Copts: Christians of Egypt, 22, 23. Jersey City, NY: The American, Canadian, Australian, and European Coptic Associations. 
Littman, D. G. (2005, February-March). A culture of hate based on jihad and martyrdom: Saudi Arabian and Egyptian schoolbooks today. Midstream, 51(2). Retrieved from www.midstreamthf.com

Lotfi, S. H., Ali, M., \& Kamel, G. (1993). El-Mowagha: Tadbeek El-Sharia El-Eslamiah Been El-Haqiqa Wa-Shiaraat El-Fitnah [The confrontation: Applying the Islamic Sharia between truth and rhetoric of splitting among Muslims]. Cairo, Egypt: Egyptian Organization of Publishing Books.

Loza, W. (2007). The Belief Diversity Scale. Unpublished Manuscript.

Loza, W. (2007). The psychology of extremism and terrorism: A Middle-Eastern perspective. Journal of Aggression \& Violent Behavior, 12(2), 141-155. http://dx.doi.org/10.1016/j.avb.2006.09.001

Loza, W. (2010a). The prevalence of Middle-Eastern extreme ideologies among some Canadians. Journal of Interpersonal Violence, 26(7), 1388-1400. http://dx.doi.org/10.1177/0886260510369133

Loza, W. (2010b). The prevalence of Middle-Eastern extremist ideologies among some Canadian offenders. Journal of Interpersonal Violence, 25(5), 919-928. http://dx.doi.org/10.1177/0886260509336966

Loza, W., El-Fatah, Y, Prinsloo, J., Hesslink, A., \& Seidler, K. (2011). The prevalence of extreme Middle-Eastern ideologies around the world. Journal of Interpersonal Violence, 26(3), 523-538. http://dx.doi.org/10.1177/0886260510363417

Manji, I. (2003). The trouble with Islam: A wake-up call for honesty and change (1st ed.). Toronto, ON: Random House Canada.

Mazarr, M. (2007). Unmodern men in the modern world: Radical Islam, terrorism, and the war on modernity. New York, NY: Cambridge University Press.

McCauley, C. (2002). Psychological issues in understanding terrorism and the response to terrorism. In C. E. Stout (Ed.), The psychology of terrorism: Theoretical understandings and perspectives (psychological dimension to war and peace; vol. 3, pp. 3-29). Westport, CT: Praeger Security International.

Mockaitis, T. R. (2007). The "new" terrorism: Myths and reality. Westport, CT: Praeger Security International.

Onuoha, F. C. (2012). Boko Haram: Nigeria's extreme Islamic sect. Al Jazeera Center for Studies. Retrieved from http://studies.aljazeera.net/ResourceGallery/media/Documents/2012/2/29/2012229113341793734BOKO\%2 0HARAM\%20NIGERIAS\%20EXTREMIST\%20ISLAMIC\%20SECT.pdf

Orbach, B. (2001). Usama Bin Laden and Al-Qa'ida: Origins and doctrines. Middle-East Review of International Affairs, 5(4), 54-68.

Pipes, D. (2008). Closing and/or countering radical Islamic media. Conference Talk given at International Conference 2008 of the International Institute for Counter-Terrorism, Herzliya, Israel.

Post, J. M., Merali, A., \& Ganor, B. (2008). The mind of the terrorist: The psychology of terrorism from IRA to al-Qaeda. International Institute for Counter-Terrorism. Retrieved from http://www.ict.org.il

Post, J. M., Sprinzak, E., \& Denny, L. M. (2003). The terrorists in their own words: interviews with thirty-five incarcerated Middle-Eastern terrorists. Terrorism and Political Violence, 15(1), 171-84.

Sageman, M. (2004). Understanding terror networks. Philadelphia, PA: University of Pennsylvania Press.

Sayyed, T. (2005, December 2). A Muslim in a Jewish land. Retrieved from http://www.jihadwatch.org/dhimmiwatch/archives/009251.php

Schwind, R. L. (2005, August 20). The London bombings hatred in Islam civil society and the Umma. Islam review. Retrieved from http://www.islamreview.com/articles/hatredinislam.shtml

Silke, A. (2008). Holy warriors: Exploring the psychological process of Jihad radicalization. European Journal of Criminology, 5(1), 99-123. http://dx.doi.org/10.1177/1477370807084226

Stern, J. (1999). The ultimate terrorists. Cambridge, MA: Harvard University Press.

Stern, J. (2003). Terror in the name of God: Why religious militants kill. New York, NY: Harper Collins Publishers.

Tanveer, A. (2005). The Muslim "marginal man". Policy, 21(1), 35-41.

\section{(c) $)$ EY}

This work is licensed under a Creative Commons Attribution 3.0 License. 